\title{
ANALISIS TINGKAT PARTISIPASI ANGKATAN KERJA BERDASARKAN KEGIATAN EKONOMI MASYARAKAT DESA TEGALSARI KECAMATAN TEGALSARI KABUPATEN BANYUWANGI TAHUN 2015
}

\author{
Vina Shofia Nur Mala ${ }^{1}$, Bambang Suyadi ${ }^{1}$, Retna Ngesti Sedyati ${ }^{1}$ \\ ${ }^{1}$ Program Studi Pendidikan Ekonomi, Fakultas Keguruan dan Ilmu Pendidikan, Universitas Jember
}

\begin{abstract}
Tegalsari Village is one of the villages is in southern district Banyuwangi.The Village is quite far from the city center and the education level of community lower to question is how villagers Tegalsari participate in the workplace. This study aims to determine how much the labor force participation rate (LFPR) Village community Tegalsari, Tegalsari District of Banyuwangi in 2015, to determine the dominant economy sectors of society and describe how labor force participation rate in the village Tegalsari. Determining where the research using purposive area. For determine respondents in this research uses a method of the population purporsive that is working age in village Tegalsari in the informal sector which includes primary sector (agriculture farm), secondary sector (home industry, trade) and tertiary sector (services). Data collection methods used consisiting of the: observation, survey, interview and documents. The results of the analysis of data obtained by the labor force participation rate in the village Tegalsari in 2015 higher by $70 \%$, which includes $67 \%$ LFPR in the informal sector and 3\% in the formal sector. Of the 67\% LFPR in the informal sector, $60 \%$ of the LFPR in the primary sector, $6 \%$ LFPR in the secondary sector and $1 \%$ in the tertiary sector.
\end{abstract}

Keywords: labor force participation rate, primary sector, secondary sector, tertiary sector

\section{PENDAHULUAN}

Desa Tegalsari merupakan salah satu desa yang terletak di bagian selatan kabupaten Banyuwangi. Wilayah desa Tegalsari 65\% merupakan daerah persawahan yang cukup subur untuk pertanian dan strategis untuk pengembangan usaha ekonomi masyarakat. Sumber daya alam yang ada cukup bervariasi merupakan salah satu faktor yang mendukung peningkatan pendapatan masyarakat Tegalsari. Namun melihat banyaknya lahan pertanian yang beralih fungsi menjadi usaha dibidang non pertanian dan perumahan penduduk. Hal ini menjadi tanda tanya besar bagaimana penduduk desa ini berpartisipasi dalam pasar tenaga kerja.

Pertambahan penduduk juga menimbulkan berbagai masalah di desa kecil ini, khususnya pada penyediaan kesempatan bagi angkatan kerja. Sebagian besar masyarakat Desa Tegalsari yang sudah mencapai usia kerja lebih memilih pekerjaan di sektor informal daripada di sektor formal. Sektor informal merupakan pilihan alternatif yang diambil masyarakat Desa Tegalsari untuk bekerja, hal ini disebabkan sektor formal menuntut masyarakat untuk berpendidikan tinggi. Dan sebagian besar masyarakat Desa Tegalsari berpendidikan rendah, sehingga banyak yang bekerja seadanya seperti menjadi petani, buruh tani, pedagang, tukang cukur dan sebagainya.

Tingkat partisipasi angkatan kerja (TPAK) sendiri merupakan suatu indikator ketenagakerjaan yang memberikan gambaran tentang penduduk yang aktif secara ekonomi dalam kegiatan sehari-hari merujuk pada suatu waktu dalam periode survei. Semakin besar jumlah penduduk yang tergolong bukan angkatan kerja, semakin kecil jumlah angkatan kerja yang mengakibatkan semakin kecil TPAK (Payaman J Simanjuntak, 2005:45). Dan banyak faktor-faktor yang mempengaruhi TPAK selain jumlah penduduk, seperti pendidikan, jenis kelamin, usia dan lain-lain. 
Sehubungan dengan hal tersebut, serta melihat perubahan tingkat pasrtisipasi masyarakat desa Tegalsari berdasarkan kegiatan ekonomi masyarakat dalam kurun waktu 2015. Peneliti tertarik untuk mengadakan penelitian tentang partisipasi angkatan kerja di sektor kegiatan ekonomi masyarakat yang meliputi sektor primer (pertanian dan peternakan), sektor sekunder (perdagangan dan industri) dan sektor tersier (jasa), dalam skripsi ini yang berjudul “Analisis Tingkat Partisipasi Angkatan Kerja Berdasarkan Kegiatan Ekonomi Masyarakat Desa Tegalsari Kecamatan Tegalsari Kabupaten Banyuwangi Tahun 2015”.

\section{METODE PENELITIAN}

Penelitian yang dilakukan ini menggunakan metode survei. Menurut Riduwan (2003) penelitian survey adalah penelitian yang dilakukan pada populasi besar maupun kecil, tetapi data yang dipelajari adalah data dari sampel yang diambil dari populasi tersebut. Metode penentuan lokasi penelitian yaitu menggunakan metode purposive area, informan utama penelitian yaitu angkatan kerja masyarakat desa Tegalsari di sektor ekonomi informal. Metode penentuan informan yaitu menggunakan populasi purposive. Pengumpulan data menggunakan wawancara dengan berpedoman pada pedoman wawancara, serta menggunakan metode observasi dan dokumen. Metode analisis data menggunakan rumus TPAK. Penelitian ini berupaya mendeskripsikan atau menjelaskan dan mencatat kondisi tingkat partisipasi angkatan kerja masyarakat Desa Tegalsari Kecamatan Tegalsari Kabupaten Banyuwangi berdasarkan kegiatan ekonomi di sektor informal.

Dalam penelitian terdapat beberapa definisi operasional konsep yang merupakan dasar dari pemikiran peneliti yang meliputi: (1) angkatan kerja yaitu masyarakat desa Tegalsari yang dalam usia kerja (15-64 tahun) yang bekerja di sektor informal, meganggur dan mencari pekerjaan. (2) tenaga kerja yaitu masyarakat desa Tegalsari yang berusia kerja (15-64 tahun) baik yang sudah bekerja, menganggur, sedang mencari kerja, mengurus rumah tangga dan penduduk yang masih bersekolah. (3) tingkat pasrtisipasi angkatan kerja (TPAK) yaitu penduduk desa Tegalsari yang sudah bekerja, menganggur dan sedang mencari pekerjaan dibandingkan dengan jumlah semua penduduk yang sudah memasuki usia kerja (15-64 tahun) baik yang sudah bekerja atau sedang mencari kerja, bersekolah dan mengurus rumah tangga.

Penentuan lokasi penelitian menggunakan metode purposive area yaitu penentuan daerah penelitian sudah ditentukan dan sudah disesuaikan dengan tujuan penelitian yaitu Desa Tegalsari, Kecamatan Tegalsari, Kabupaten Banyuwangi, atas dasar pertimbangan hasil observasi awal yang dilakukan. Metode penentuan responden penelitian adalah metode populasi purposive yaitu semua angkatan kerja yang berjumlah 6.851 orang dan angkatan kerja sektor informal berjumlah 6.561 orang di Desa Tegalsari Kecamatan Tegalsari Kabupaten Banyuwangi.

Jenis data pada penelitian di Desa Tegalsari ini dibagi menjadi dua yaitu: pertama data primer, diperoleh dengan melihat dan mengadakan pengamatan secara langsung tentang kondisi masyarakat dan tingkat partisipasi angkatan kerja desa Tegalsari. Kedua data sekunder yaitu data yang diperoleh dari berbagai sumber terkait, bisa melalui lembaga atau instansi di Desa tegalsari, Badan Pusat Statistik dan pustaka-pustaka lain sebagai penunjang.

Sumber data dalam penelitian ini diperoleh dari responden, yaitu masyarakat Desa Tegalsari yang termasuk tenaga kerja dan angkatan kerja melalui observasi dan wawancara. 
Serta dokumen, yaitu pencatatan dokumen tentang jumlah masyarakat Desa Tegalsari Kecamatan Tegalsari Kabupaten Banyuwangi yang termasuk dalam tenaga kerja dan angkatan kerja serta informasi yang terkait dari instansi dalam penelitian ini.

Metode pengumpulan data menggunakan observasi, wawancara dan dokumen. Metode pengolahan data menggunakan pengkodean data (coding) dan editing. Sedangkan analisis tingkat partisipasi angkatan kerja menggunakan rumus TPAK, seperti yang dikemukakan Simanjuntak (2005:45) sebagai berikut:

Tenaga kerja $=$ Angkatan kerja + Bukan angkatan kerja

Angkatan kerja $=$ yang bekerja + penganggur

$$
\mathrm{TPAK}=\frac{\text { Jumlah angkatan kerja }}{\text { Jumlah tenaga kerja }} \times 100 \%
$$

Setelah mengetahui jumlah TPAK, peneliti menggunakan alanisis deskriptif yaitu menceritakan keadaan yang sesungguhnya terjadi di tempat penelitian. Hasil dari jumlah TPAK tersebut ditentukan tinggi rendahnya melalui tabel kriteria TPAK menurut data BPS yaitu sebagai berikut:

\begin{tabular}{|c|c|}
\hline Frekuensi & Keterangan \\
\hline $64,13 \%>$ & Tinggi \\
$<64,13 \%$ & Rendah \\
\hline
\end{tabular}

Sumber: Data BPS Kabupaten Banyuwangi 2015

\section{HASIL DAN PEMBAHASAN}

\section{Hasil Penelitian}

Gambaran Umum Lokasi Penelitian

Lokasi penelitian dalam penelitian ini di Desa Tegalsari Kecamatan Tegalsari Kabupaten Banyuwangi. Memiliki luas $17,96 \mathrm{~km}^{2}$ yang $65 \%$ dari luasnya adalah area persawahan dan terdiri dari tiga dusun yaitu Krajan 1, Krajan 2 dan Mojoroto. Lokasi Desa tegalsari yang jauh dari pusat Kota Banyuwangi dan pusat kegiatan ekonomi seperti daerah Genteng membuat masyarakat sulit dalam mencari pekerjaan.

Desa Tegalsari memiliki penduduk sebesar 12.163 jiwa dengan 3.393 KK (Kepala Keluarga) yang terdiri dari 2.326 anak-anak dan lansia, masyarakat berusia kerja sebanyak 9.837 orang. Penduduk usia kerja atau biasa disebut tenaga kerja terdiri dari angkatan kerja dan bukan angkatan kerja. Angkatan kerja berjumlah 6.851 orang dan bukan angkatan kerja berjumlah 2.986. Mata pencaharian penduduk Desa Tegalsari yaitu sebagai petani, peternak, buruh tani, pedagang, pegawai negeri sipil, pegawai swasta dan sektor jasa.

Desa Tegalsari memiliki jumlah penduduk yang relatif banyak, namun faktor pendukung dalam kegiatan ekonomi yang masih kurang dan dengan pendidikan yang relatif rendah sehingga menyebabkan banyak penduduk memilih untuk melakukan pekerjaan apa saja untuk memenuhi kebutuhan hidup. Hal ini yang menyebabkan banyak penduduk Desa Tegalsari yang memilih bekerja di sektor informal daripada di sektor formal. Berdasarkan 
penelitian jumlah penduduk yang bekerja di sektor formal dan informal dapat dijelaskan sebagai berikut:

Tabel 1. Angkatan Kerja Sektor Formal dan Informal

\begin{tabular}{|l|l|l|l|}
\hline No. & Sektor & Jumlah & Persentase (\%) \\
\hline 1. & Formal & 290 & $4 \%$ \\
2. & Informal & 6.561 & $96 \%$ \\
\hline \multicolumn{2}{|l|}{ Jumlah } & 6.851 & 100 \\
\hline
\end{tabular}

Sumber : Data Primer diolah (2015)

Gambaran Umum Responden

Responden dalam penelitian ini adalah penduduk Desa Tegalsari yang termasuk angkatan kerja yang bekerja di sektor informal meliputi sektor primer (pertanian, peternakan), sektor sekunder (industri rumah tangga, pedagang) dan sektor tersier/jasa (bengkel, salon, tukang kayu).

\section{a. Tenaga Kerja}

Masyarakat usia kerja atau tenaga kerja di Desa Tegalsari tidak semuanya termasuk tenaga kerja, karena penduduk yang termasuk tenaga kerja yaitu penduduk yang berusia 15-64 tahun. Simanjuntak (2005:2) menyatakan bahwa penduduk yang dianggap sebagai tenaga kerja potensial atau penduduk usia kerja yaitu penduduk yang telah mencapai umur 15-64 tahun dan berpotensi untuk memproduksi barang dan jasa. Berikut tabel tentang jumlah penduduk usia kerja masyarakat Desa Tegalsari Kecamatan Tegalsari Kabupaten Banyuwangi berdasarkan jenis kelamin sebagai berikut:

Tabel 2. Jumlah Tenaga Kerja

\begin{tabular}{|c|c|c|c|}
\hline No. & Jenis Kelamin & Jumlah & Persentase $(\%)$ \\
\hline 1. & Laki - Laki & 4.965 & $50,5 \%$ \\
\hline 2. & Perempuan & 4.872 & $49,5 \%$ \\
\hline \multicolumn{2}{|r|}{ Jumlah } & 9.837 & $100 \%$ \\
\hline
\end{tabular}

Sumber: Data primer (2015) diolah

Berdasarkan tabel 2 dapat diketahui jumlah masyarakat usia kerja di Desa Tegalsari Kecamatan Tegalsari Kabupaten Banyuwangi sebanyak 9.837 orang, yang terdiri dari laki-laki sebanyak 4.965 orang atau $50,5 \%$ dan yang berjenis kelamin perempuan sebanyak 4.872 orang atau $49,5 \%$.

Angkatan kerja adalah masyarakat yang sudah memasuki usia kerja 15-64 tahun dan sudah bekerja, sedang mencari pekerjaan dan menganggur, sedangkan bukan angkatan kerja adalah penduduk usia kerja yang masih bersekolah, mengurus rumah tangga dan golongan lainlain atau penerima pendapatan. Dijelaskan pada tabel sebagai berikut:

Tabel 4.3 Angkatan Kerja dan Bukan Angkatan Kerja

\begin{tabular}{|c|c|c|c|}
\hline No. & Penduduk Usia Kerja & Jumlah & Persentase (\%) \\
\hline 1. & Angkatan Kerja & 6.851 & $69,6 \%$ \\
\hline 2. & Bukan Angkatan Kerja & 2.986 & $30,4 \%$ \\
\hline \multicolumn{2}{|r|}{ Jumlah } & 9.837 & $100 \%$ \\
\hline
\end{tabular}

Sumber: Data primer (2015) diolah 
Berdasarkan tabel 4.3 penduduk usia kerja yang termasuk angkatan kerja sebanyak 6.851 orang atau $69,6 \%$ sedangkan yang bukan angkatan kerja sebanyak 2986 orang atau $30,4 \%$.

\section{b. Angkatan Kerja}

Adapun penjelasan secara lengkap jumlah angkatan kerja berdasarkan jenis kelamin di Desa Tegalsari Kecamatan Tegalsari Kabupaten Banyuwangi tersusun pada tabel sebagai berikut:

Tabel 4. Jumlah Angkatan Kerja Berdasarkan Jenis Kelamin

\begin{tabular}{|c|c|c|c|}
\hline No. & Jenis Kelamin & Jumlah & Persentase (\%) \\
\hline 1. & Laki-laki & 3.891 & $56,8 \%$ \\
\hline 2. & Perempuan & 2.960 & $43,2 \%$ \\
\hline \multicolumn{2}{|r|}{ Jumlah } & 6.851 & $100 \%$ \\
\hline
\end{tabular}

Sumber: Data primer (2015) diolah

Berdasarkan tabel diatas dapat diketahui bahwa angkatan kerja di Desa Tegalsari Kecamatan Tegalsari Kabupaten Banyuwangi yang berjenis kelamin laki-laki berjumlah 3.891 orang atau 56,8\% lebih banyak daripada yang berjenis kelamin perempuan berjumlah 2.960 orang atau 43,2 \%. Angkatan kerja masyarakat Desa Tegalsari Kecamatan Tegalsari Kabupaten Banyuwangi tidak semua memiliki pekerjaan, karena angkatan kerja terdiri dari masyarakat yang bekerja, sedang mencari pekerjaan dan menganggur. Dijelaskan pada tabel sebagai berikut:

Tabel 5. Jumlah Angkatan Kerja yang Bekerja, Menganggur dan Sedang Mencari Kerja

\begin{tabular}{|c|c|c|c|}
\hline No. & Angkatan Kerja & Jumlah & Persentase $(\%)$ \\
\hline 1. & Bekerja & 6.204 & $90,6 \%$ \\
\hline 2. & Menganggur & 404 & $5,9 \%$ \\
\hline 3. & Sedang Mencari Kerja & 243 & $3,5 \%$ \\
\hline \multicolumn{2}{|r|}{ Jumlah } & 6.851 & $100 \%$ \\
\hline
\end{tabular}

Sumber: Data primer (2015) diolah

Berdasarkan tabel diatas dapat diketahui bahwa angkatan kerja yang sudah bekerja tersebut sebagian besar bekerja. Sedangkan yang lain sedang mencari pekerjaan atau memilih menganggur untuk mendapatkan pekerjaan yang sesuai dengan keahlian mereka. Lebih jelasnya dapat dilihat pada tabel jenis pekerjaan masyarakat Desa Tegalsari sebagai berikut:

Tabel 6 Jumlah Penduduk yang Bekerja di Sektor Ekonomi Informal

\begin{tabular}{|c|l|c|c|}
\hline No. & \multicolumn{1}{|c|}{ Sektor Ekonomi Informal } & Jumlah & Persentase (\%) \\
\hline 1. & Sektor Primer & 4.454 & $67,89 \%$ \\
& - Petani & 1.449 & $22,09 \%$ \\
& - Buruh Tani & 10 & $0,15 \%$ \\
2. Peternak & Sektor Sekunder & 551 & $8,4 \%$ \\
& - Pedagang & 12 & $0,18 \%$ \\
3. Industri Rumah Tangga & Sektor Tersier & 3 & $0,05 \%$ \\
& - Dukun Bayi & 2 & $0,03 \%$ \\
\hline
\end{tabular}




\begin{tabular}{|c|c|c|}
\hline $\begin{array}{l}\text { - Tukang Batu } \\
\text { - Tukang Kayu } \\
\text { - Tukang Jahit } \\
\text { - Sopir } \\
\text { - Bengkel Sepeda Motor } \\
\text { - Bengkel Sepeda Dayung } \\
\text { - Reparasi Elektronik } \\
\text { - Tukang Cukur } \\
\text { - Tukang Ojek } \\
\text { - Tukang Besi }\end{array}$ & $\begin{array}{l}18 \\
21 \\
12 \\
6 \\
7 \\
4 \\
3 \\
2 \\
4 \\
3\end{array}$ & $\begin{array}{c}0,27 \% \\
0,32 \% \\
0,18 \\
0,09 \% \\
0,11 \% \\
0,06 \% \\
0,05 \% \\
0,03 \% \\
0,06 \% \\
0,05 \%\end{array}$ \\
\hline Jumlah & 6.561 & $100 \%$ \\
\hline
\end{tabular}

Sumber: Data primer (2015) diolah

Berdasarkan tabel 6 menunjukkan bahwa masyarakat Desa Tegalsari mayoritas bekerja sebagai petani dengan jumlah 4.545 atau sebesar 67,89\%. Dari tabel tersebut terlihat bahwa mayoritas penduduk Desa Tegalsari Kecamatan Tegalsari Kabupaten Banyuwangi bekerja di sektor primer yaitu petani sedangkan sektor tersier atau jasa menempati urutan terendah sebesar $0,03 \%$ meliputi salon kecantikan dan tukang cukur

\section{c. Karakteristik Responden Berdasarkan Usia}

Berdasarkan penelitian yang dilakukan kepada angkatan kerja di Desa Tegalsari Kecamatan Tegalsari Kabupaten Banyuwangi yang menjadi responden dalam penelitian ini diperoleh data berdasarkan tingkat usia responden. Pengklasifikasian responden berdasarkan usia dapat dilihat pada tabel berikut ini.

Tabel 7 Klasifikasi Responden Angkatan Kerja Berdasarkan Tingkat Usia
\begin{tabular}{|c|c|c|}
\hline Golongan Umur & Jumlah & Persentase (\%) \\
\hline $15-19$ & 226 & $3,3 \%$ \\
$20-24$ & 623 & $9,1 \%$ \\
$25-29$ & 897 & $13,1 \%$ \\
$30-34$ & 1.082 & $15,8 \%$ \\
$35-39$ & 1.622 & $23,7 \%$ \\
$40-44$ & 918 & $13,4 \%$ \\
$45-49$ & 519 & $7,6 \%$ \\
$50-54$ & 375 & $5,5 \%$ \\
$55-59$ & 315 & $4,6 \%$ \\
$60-64$ & 274 & $4 \%$ \\
\hline Jumlah & 6.851 & $100 \%$ \\
\hline
\end{tabular}

Sumber: Data Primer diolah (2015)

Berdasarkan tabel 7 diatas, dapat diketahui bahwa angkatan kerja di Desa Tegalsari Kecamatan Tegalsari Kabupaten Banyuwangi yang menjadi responden dalam penelitian ini terbanyak pada usia 35 - 39 tahun sebanyak 1.622 atau sebesar 23,7\%. Dan paling rendah pada rentang usia 15 - 19 tahun sebanyak 226 atau sebesar 3,3\%. Pada rentang usia 35 - 39 tahun, banyak masyarakat Desa Tegalsari telah berkeluarga sehingga mereka banyak yang terjun ke dunia kerja untuk mencukupi kebutuhan keluarga. Sedangkan pada rentang usia 15-19 tahun 
sebagian besar masyarakat Desa Tegalsari masih bersekolah sehingga pada usia tersebut tidak banyak masyarakat yang bekerja karena masih ingin melanjutkan pendidikan.

\section{Pembahasan}

Berdasarkan hasil penelitian dan analisis data dalam penelitian ini adalah meliputi usia kerja dan angkatan kerja masyarakat Desa Tegalsari Kecamatan Tegalsari Kabupaten Banyuwangi untuk mengetahui jumlah TPAK dengan menggunakan rumus TPAK dan sektor yang dominan dimasuki oleh angkatan kerja di Desa tersebut.

Berdasarkan tabel menunjukkan bahwa jumlah angkatan kerja di Desa Tegalsari Kecamatan Tegalsari Kabupaten Banyuwangi berjumlah 6.851 orang dan yang termasuk bukan angkatan kerja 2.986 orang, sehingga jumlah penduduk usia kerja di Desa Tegalsari Kecamatan Tegalsari Kabupaten Banyuwangi berjumlah 9.837 orang. Tingkat partisipasi angkatan kerja (TPAK) Desa Tegalsari Kecamatan Tegalsari Kabupaten Banyuwangi dapat dihitung menggunakan rumus:

$$
\begin{aligned}
\text { TPAK } & =\frac{\text { Angkatan Kerja }}{\text { Tenaga Kerja }} \times 100 \% \\
\text { TPAK } & =\frac{6.851}{9.837} \times 100 \% \\
\text { TPAK } & =70 \%
\end{aligned}
$$

Berdasarkan hasil perhitungan tersebut dapat diketahui bahwa tingkat partisipasi angkatan kerja masyarakat Desa Tegalsari Kecamatan Tegalsari Kabupaten Banyuwangi tinggi yaitu sebesar $70 \%$, angka tersebut menunjukkan bahwa dari 100 orang tenaga kerja terdapat 70 orang angkatan kerja, yaitu mereka yang bekerja, menganggur dan sedang mencari kerja. Tinggi rendahnya tingkat partisipasi angkatan kerja dapat dilihat berdasarkan data BPS Kabupaten Banyuwangi. Berikut ini tabel kriteria TPAK menurut data BPS Kabupaten Banyuwangi:

Tabel 8 Kriteria Tingkat Partisipasi Angkatan Kerja

\begin{tabular}{|c|c|}
\hline Frekuensi & Keterangan \\
\hline $64,13 \%>$ & Tinggi \\
$<64,13 \%$ & Rendah \\
\hline
\end{tabular}

Sumber: Data BPS Kabupaten Banyuwangi 2015

Berdasarkan tabel tersebut menunjukkan bahwa jumlah tingkat partisipasi angkatan kerja yang lebuh dari 64,13\% adalah tinggi, sedangkan jumlah tingkat partisipasi angkatan kerja yang kurang dari $64,13 \%$ adalah rendah.

Sesuai tabel 4.1, dari jumlah angkatan kerja sebesar 6.851 orang terdapat 290 orang bekerja di sektor formal dan 6.561 orang. Dari hasil TPAK keseluruhan dengan hasil 70\% terdapat TPAK sektor formal dan informal. Maka penghitungan TPAK angkatan kerja formal dan angkatan kerja informal sebagai berikut: 
a. Sektor formal

$$
\begin{aligned}
\text { TPAK } & =\frac{\text { Angkatan Kerja }}{\text { Tenaga Kerja }} \times 100 \% \\
\text { TPAK } & =\frac{290}{9.837} \times 100 \% \\
\text { TPAK } & =3 \%
\end{aligned}
$$

b. Sektor informal

$$
\begin{aligned}
\text { TPAK } & =\frac{\text { Angkatan Kerja }}{\text { Tenaga Kerja }} \times 100 \% \\
\text { TPAK } & =\frac{6.561}{9.837} \times 100 \% \\
\text { TPAK } & =67 \%
\end{aligned}
$$

Berdasarkan hasil penghitungan tersebut menunjukkan bahwa TPAK masyarakat Desa Tegalsari di sektor informal sebesar 67\% dari TPAK keseluruhan sebesar 70\%. Dapat diartikan bahwa dari 100 orang tenaga kerja, 70 orang merupakan angkatan kerja yang terdiri dari 67 orang angkatan kerja sektor informal dan 3 orang bekerja di sektor formal. Dalam kegiatan ekonomi sektor informal terdapat tiga sektor yaitu sektor primer, sekunder dan tersier berikut penghitungan TPAK di tiga sektor tersebut:

a. Sektor Primer

$$
\begin{aligned}
\text { TPAK } & =\frac{\text { Angkatan Kerja }}{\text { Tenaga Kerja }} \times 100 \% \\
\text { TPAK } & =\frac{5.913}{9.837} \times 100 \% \\
\text { TPAK } & =60 \%
\end{aligned}
$$

b. Sektor Sekunder

$$
\begin{aligned}
\text { TPAK } & =\frac{\text { Angkatan Kerja }}{\text { Tenaga Kerja }} \times 100 \% \\
\text { TPAK } & =\frac{563}{9.837} \times 100 \% \\
\text { TPAK } & =6 \%
\end{aligned}
$$

c. Sektor Tersier

$$
\begin{aligned}
\text { TPAK } & =\frac{\text { Angkatan Kerja }}{\text { Tenaga Kerja }} \times 100 \% \\
\text { TPAK } & =\frac{85}{9.837} \times 100 \% \\
\text { TPAK } & =1 \%
\end{aligned}
$$


Berdasarkan perhitungan diatas menunjukkan bahwa dari 67\% TPAK di sektor informal, sektor primer sebesar $60 \%$, sektor sekunder sebesar $6 \%$ dan sektor tersier sebesar $1 \%$. Hal ini berarti dari 100 tenaga kerja terdapat 67 orang angkatan kerja di sektor informal, diantaranya 60 orang di sektor primer (pertanian, peternakan), 6 orang di sektor sekunder (perdagangan, industri rumah tangga) dan 1 orang di sektor tersier (jasa).

Berdasarkan pembahasan di atas, dapat disimpulkan bahwa tingkat partisipasi masyarakat Desa Tegalsari Kecamatan Tegalsari Kabupaten Banyuwangi tinggi disebabkan oleh rendahnya pendidikan yang berakibat banyaknya penduduk yang memilih untuk bekerja daripada bersekolah dan mengurus rumah tangga, sehingga jumlah angkatan kerja meningkat dan mengakibatkan jumlah tingkat partisipasi angkatan kerja di Desa Tegalsari Kecamatan Tegalsari Kabupaten Banyuwangi tinggi.

Sektor yang dominan dimasuki oleh masyarakat Desa Tegalsari adalah sektor primer. Dari hasil penelitian yang dilakukan banyaknya masyarakat memilih bekerja di sektor primer terutama pertanian dikarenakan selain lahan pertanian yang masih luas, menjadi petani tidak diperlukan pendidikan tinggi dan keahlian khusus. Apabila pada masa penggarapan sawah, banyak buruh tani yang bisa dipekerjakan untuk membantu menggarap sawah. Jika pada masa tunggu, banyak petani yang mempunyai pekerjaan sampingan seperti berladang, beternak kambing atau sapi, berdagang dan sebagainya.

\section{KESIMPULAN DAN SARAN \\ Kesimpulan}

Berdasarkan hasil penelitian dan analisis data yang dilakukan dapat disimpulkan bahwa masyarakat Desa Tegalsari Kecamatan Tegalsari Kabupaten Banyuwangi mempunyai TPAK yang tinggi sebesar $70 \%$. Hal tersebut berarti dari 100 tenaga kerja terdapat 70 orang angkatan kerja yang ada di Desa Tegalsari. Sektor ekonomi yang banyak dimasuki oleh masyarakat Desa Tegalsari untuk bekerja adalah sektor ekonomi informal dengan hasil TPAK 67\% dari 70\% TPAK keseluruhan. Sektor ekonomi informal meliputi sektor primer (pertanian dan peternakan), sektor sekunder (perdagangan dan industri rumah tangga) dan tersier (jasa).

Sektor ekonomi informal yang dominan dimasuki oleh masyarakat Desa Tegalsari adalah sektor primer sebanyak $60 \%$ dari jumlah $67 \%$ hasil TPAK di sektor informal. Tingkat partisipasi angkatan kerja di Desa Tegalsari tinggi dikarenakan pendidikan masyarakat yang rendah berakibat pada pekerjaan yang mereka lakukan. Pekerjaan denagn pendapatan rendah mengakibatkan dalam satu keluarga tidak hanya kepala keluarga saja yang bekerja, ibu rumah tangga dan anak juga bekerja untuk memuhi kebutuhan hidup. Pekerjaan di sektor informal banyak yang diciptakan sendiri oleh masyarakat dengan melihat peluang kerja yang ada di Desa Tegalsari tersebut.

\section{Saran}

Berdasarkan hasil kesimpulan di atas maka peneliti dapat memberikan saran kepada masyarakat Desa Tegalsari bahwa pendidikan itu berpengaruh dalam mendapatkan pekerjaan serta besar kecilnya pendapatan yang diperoleh. Maka dari itu masyarakat Desa Tegalsari diharapkan untuk sadar akan pentingnya pendidikan untuk kehidupan yang lebih baik dari sekarang. 
Dan juga harus didukung oleh pemerintah terutama perangkat desa, untuk memberdayakan masyarakat dengan mengadakan pelatihan atau kursus yang mengutamakan pada padat karya. Mengadakan penyuluhan kepada masyarakat tentang pentingnya pendidikan bagi anak-anak mereka. Sehingga ketika sudah mencapai usia kerja akan menjadi angkatan kerja yang kompeten di bidangnya.

\section{DAFTAR BACAAN}

BPS Kabupaten Banyuwangi \& BAPEDDA. 2014. Kabupaten Banyuwangi dalam Angka. Banyuwangi: BPS Kabupaten Banyuwangi

International Labour Organization (ILO)

Riduwan.2003. Dasar-dasar Statistika. Bandung: Alfabeta

Simanjuntak, Payaman J. 2001. Ekonomi Sumber Daya Manusia. Jakarta: Fakultas Ekonomi Universitas Indonesia

Simanjuntak, Payaman J. 2005, Ekonomi Sumber Daya Manusia. Jakarta: Fakultas Ekonomi Universitas Indonesia.

Undang - Undang Ketenagakerjaan No.13 Tahun 2003 